\title{
PERFORMANCE MEASUREMENT ANALYSIS USING BALANCE SCORECARD IN dr. H. SOEWONDO KENDAL HOSPITAL
}

\author{
Yollanda Lakshinta Harningrum \\ Yogyakarta State University Accounting Study Program \\ Yollandalakshinta@gmail.com \\ Mimin Nur Aisyah \\ Yogyakarta State University Accounting Study Program \\ Mimin_nuraisyah@uny.ac.id
}

\begin{abstract}
Abstrak: Analisis Pengukuran Kinerja Dengan Pendekatan Balance Scorecard di RSUD dr. H. Soewondo Kendal. Tujuan penelitian ini adalah untuk mengevaluasi kinerja RSUD dr. H. Soewondo Kendal dengan menggunakan Balance Scorecard (BSC). Penelitian ini merupakan penelitian studi kasus dengan menggunakan teknik analisis deskriptif kuantitatif. Sampel penelitian berjumlah 180 responden yang terdiri dari 94 pasien/ keluarga pasien dan 86 karyawan rumah sakit. Data dikumpulkan melalui metode dokumentasi dan kuesioner. Hasil penelitian menunjukkan bahwa: (1) Perspektif keuangan menunjukkan kinerja sangat-sangat baik mencapai skor 13 dari 15 (86,6\%); (2) Perspektif pelanggan menunjukkan kinerja baik mencapai skor 10 dari 14 (71,42\%); (3) Perspektif proses bisnis internal menunjukkan kinerja yang cukup mencapai skor 5 dari 10 (50\%); dan (4) Perspektif pembelajaran dan pertumbuhan menunjukkan kinerja baik mencapai skor 8 dari 13 (61,54\%). Secara keseluruhan, kinerja RSUD dr. H. Soewondo Kendal dinilai baik dengan skor 36 dari 52 (67,17\%).
\end{abstract}

Kata kunci: Pengukuran Kinerja, Balance Scorecard, Kinerja Rumah Sakit

Abstract: Performance Measurement Analysis Using Balance Scorecard in dr. H. Soewondo Kendal Hospital. The purpose of this study is to evaluate the performance of RSUD dr. H. Soewondo Kendal by using the Balance Scorecard (BSC). This research is a case study research using quantitative descriptive analysis techniques. The research sampels included 180 respondents consisting of 94 patients' / patients' families and 86 hospital employees. Data was collected through documentation and questionnaire methods. The results show that: (1) Financial perspective shows a very very good performance reaching a score of 13 out of 15 (86.6\%); (2) The customer perspective shows good performance reaching a score of 10 out of 14 (71.42\%); (3) Internal business process perspective shows sufficient performance to reach a score of 5 out of $10(50 \%)$; and (4) Learning and growth perspective shows good performance reaching a score of 8 out of 13 (61.54\%). Overall, the performance of RSUD $d r$. H. Soewondo Kendal was rated as good with a score of 36 out of 52 (67.17\%).

Keywords: Performance Measurement, Balance Scorecard, Hospital Performance

\section{PRELIMINARY}

Wibowo (2011: 229) explains that performance measurement includes the activities to determine whether it is necessary to conduct an evaluation of a predetermined plan, or whether the performance can be carried out according to a specified time schedule, or whether the resulting performance is as expected.

So far, performance measurement is generally conducted traditionally or focuses on the financial aspect. Measuring a company's financial performance is often considered sufficient to describe management's performance. According to 


\section{Nominal: Barometer Riset Akuntansi dan Manajemen}

P-ISSN: 2303-2065 E-ISSN: 2502-5430

Volume 10 No 1 (2021)

Kaplan \& Norton (2000), performance measurements that are only viewed from a financial perspective will result in company orientation that leads to short-term interests, without regard to the company's long-term survival. The Balanced Scorecard (BSC) is an attempt to balance the measurement of financial aspects with non-financial aspects. The Balanced Scorecard includes four perspectives, namely financial perspective, customer perspective, internal business perspective, and learning and growth perspective.

Balanced Scorecard is a performance management tool that can help organizations to translate vision and strategy into action by utilizing a set of financial and non-financial indicators that are all intertwined in a causal relationship (Luis \& Biromo, 2007: 16). For its advantages, Balance Scorecard is now widely applied in various organization including in public sector organizations. In the hospitals for example, Balance Scorecard will help to align organizational processes such as budgeting, risk management and analytics with strategic priorities.

With the BSC, the hospital will be given a long-term picture of its success. In the financial aspect, the hospital must be able to manage money well to keep cash stable. This will have an impact on the adequacy of information regarding financial performance.
In addition to the financial aspects, an assessment of customer needs is also needed in order to provide maximum service. With the assessment of customer needs, customer satisfaction with health services can continue to be improved. Monitoring evaluation will be very important to dig up information about customer needs. When customer needs have not been met, it will lead to customer complaints.

Based on the perspective of internal business processes, the organization determines the size and synergy of each work unit. The leaders must complete the organization's internal procedures to ensure everything is done by the specified methods.

In terms of the latter perspective, namely the learning and growth perspective, the hospital can find out how employee productivity is and how to improve employee skills. Employees become an important element that must be maintained by the organization. Without employees, the organization's growth and development process will face many obstacles.

Dr. H. Soewondo Hospital is a government-owned hospital in Kendal, Central Java. Based on a preliminary asessment, it requires an analysis of performance measurement of the Balanced Scorecard. 


\section{LITERATURE REVIEW}

Mulyadi (2001: 1) argues that the Balanced Scorecard is a card used to record a person's performance score. The word balanced is intended to show that personnel performance is measured in a balanced manner from two aspects: financial and nonfinancial, short-term and long-term, internal and external.

The financial perspective is still used in the Balance Scorecard, because financial measures indicate whether the planning and implementation of organization strategies provide improvements or not to increase profits. To find out the financial performance of dr. H. Soewondo Kendal Hospital, the measurement of financial performance is carried out using the value for money method. Value for Money is a concept of managing public sector organizations based on three main elements, namely economy, efficiency, and effectiveness (Mardiasmo, 2002).

The economy is related to the extent to which public sector organizations minimize the input resources used, namely avoiding wasteful and unproductive expenditure. Effectiveness is the level of achievement of program results with a set target. Efficiency is the ratio of output/input associated with performance standards or targets that have been set.
The Customer Perspective identifies customers and market segments that will be entered. Market segment is a source that will be a component of the organization's financial goals. According to Kaplan \& Norton (2001), attention must be paid to from the customer's perspective, namely Market Share, Customer Retention, Customer Acquisition, Customer Satisfaction, and Customer Profitability.

The Internal Business Process Perspective usually develop goals and measures for this perspective after formulating objectives and measures for financial and customer perspectives. In this internal business process perspective, there are three stages that must be carried out, namely The Innovation Stage, Operation Phase, and After Sales Stage.

In Learning and Growth Perspective there are important factors that must be note, namely Employee Retention, Level of Employee Training, Employee Productivity, as well as Level of Employee Satisfaction.

\section{RESEARCH METHODS}

\section{Research Design}

This research is a quantitative descriptive using case study. Descriptive research is used to determine the existence of an independent variable on one or more variables without making a comparison of the variables themselves and looking for 
Nominal: Barometer Riset Akuntansi dan Manajemen

P-ISSN: 2303-2065 E-ISSN: 2502-5430

Volume 10 No 1 (2021)

relationships with other variables (Sugiyono, 2017). Data collection techniques in this study used primary and secondary data.

\section{Place and Time of Research}

The research was carried out on February to April 2020. The location of dr. H. Soewondo Kendal Hospital is on Jl. Laut No.21, Ngilir, Kec. Kendal, Kendal Regency, Central Java.

\section{Subjects and Objects}

The subjects of this study included 94 patients/families of inpatients and 86 employees of dr. H. Soewondo Kendal Hospital. The research object is the performance of dr. H. Soewondo Kendal Hospital in 2019 viewed from 4 aspects of the Balance Scorecard. The respondents sample size is determined using the Solvin formula.

\section{Data Collection Techniques and Instruments}

Primary data is data obtained directly from research sources or without going through intermediaries. In this study, it was obtained from the distribution of customer and employee satisfaction questionnaires.

Secondary data is data obtained from companies that have been processed and obtained through documents. It was obtained from the official website of dr. H. Soewondo Kendal Hospital and from the hospital documentation.

a. Financial Perspective

Measurement of financial performance is carried out using the value for money method by assessing three basic ratios, namely economic, effectiveness, and efficiency ratios.

The economic ratio has the objective to see the realization of operational expenditure from a predetermined expenditure budget. The economic value of financial performance can be calculated by the formula:

$$
\begin{aligned}
& \text { Ekonomic Ratio } \\
& =\frac{\text { Realized Operating Expenditures }}{\text { Operating Expenditures Budget }} \times 100 \%
\end{aligned}
$$

Effectiveness ratios are used to determine the ability of hospitals to achieve budgeted income targets. The effective value is obtained by the formula:

$$
\begin{aligned}
& \text { Effectiveness Ratio } \\
& =\frac{\text { hospital revenue realization }}{\text { hospital revenue budget }} \times 100 \%
\end{aligned}
$$

Efficiency ratio is used to see the comparison between revenue realization and budget realization. Efficiency values obtained by the formula:

$$
\begin{aligned}
& \text { Efficiency Ratio } \\
& =\frac{\text { Realized Operational Expenditures }}{\text { Operating Income Budget }} \times 100 \%
\end{aligned}
$$

b. Customer Perspective

Customer Perspective is measured by Customer Retention, Customer Acquisition, and Customer Satisfaction. 


\section{Nominal: Barometer Riset Akuntansi dan Manajemen}

P-ISSN: 2303-2065 E-ISSN: 2502-5430

Volume 10 No 1 (2021)

Customer Retention shows the ability of the hospital in maintaining relationships with customers. Customer Retention is measured using the following formula:

$$
\begin{aligned}
& \text { Customer Retention } \\
& =\frac{\text { Number of Old Customers }}{\text { Number of Customers }} \times 100 \%
\end{aligned}
$$

Customer Acquisition shows the level at which a business unit is able to attract new customers. Customer Acquisition is measured by the formula:

$$
\begin{aligned}
& \text { Customer Acquisition } \\
& =\frac{\text { Number of New Customers }}{\text { Number of Customers }} \times 100 \%
\end{aligned}
$$

Customer Satisfaction aims to find out how patients see the hospital in carrying out the process of health care in accordance with customer expectations. The level of customer satisfaction in this study will be measured by questionnaire.

\section{c. Internal Business Perspective}

Internal Business Perspective is measured by Bed Occupancy Rate (BOR), Average Length of Stay (ALOS), Internal Turnover (TOI), Net Death Rate (NDR), and Gross Death Rate (GDR).

Bed Occupancy Rate (BOR) gives a picture of high and low levels utilization of hospital beds.

$$
\begin{aligned}
& \text { BOR } \\
& =\frac{\text { Number of Hospital Treatment Days }}{\text { Number of beds } x \text { Number of Days }} \times 100 \%
\end{aligned}
$$

Average Length of Stay (ALOS) shows average length of time a patient is treated. In general, the ideal ALOS value is between 69 days. The formula for calculating ALOS is:

$$
\text { ALOS }=\frac{\text { Number of Hospital Treatment Days }}{\text { Number of patients (life }+ \text { death })}
$$

Internal Turnover (TOI) shows patients turnover cycle. Ideally, an empty bed is not filled in the range of 1-3 days. The formula for calculating TOI is:

TOI

$=\frac{(\text { Number of beds } x \text { Number of days })-\text { Care Day }}{\text { Number of Patients Out (alive }+ \text { dead })}$

Net Death Rate (NDR) shows death rate 48 hours after being treated for every 1000 patients discharged. The ideal NDR value should not be more than 25 per 1000 sufferers quit.

NDR

$=\frac{\text { Number of Dead Patients }>48 \text { hour }}{\text { Number of Patients Out (alive }+ \text { dead })} \times 1000 \%$

Gross Death Rate (GDR) shows general mortality rate for every 1000 sufferers discharged. The ideal GDR value should not be more than 45 per 1000 sufferers out, unless there are special events such as epidemics, natural disasters, war and others. The formula for calculating GDR is: GDR

$=\frac{\text { Total number of dead patients }}{\text { Number of Patients Out (alive }+ \text { dead })} \times 1000 \%$

d. Learning and Growth Perspective 
Learning and Growth Perspective is measured by Employee Retention, Employee Training Level, Employee Productivity, and Employee Satisfaction.

Employee Retention

$=\frac{\text { Number of Employees Out }}{\text { Number of employees }} \times 100 \%$

Measurement of employee retention indicators aims to measure the ability of hospitals to maintain good relations with employees. Employee Retention is considered good, if during the observation period the results of the calculation of employee retention have decreased, is considered fair if it is constant and is judged to be poor when experiencing an increase.

$$
\begin{aligned}
& \text { Employee Training Level } \\
& =\frac{\text { Number of Employees Trained }}{\text { Number of employees }} \times 100 \%
\end{aligned}
$$

The employee training level indicator is used to measure how many hospitals provide training to their employees. The level of employee training is considered good, if during the observation period the results of the calculation of employee training have increased, it is considered to be fair if it is constant and judged to be poor if it has decreased.

$$
\begin{aligned}
& \text { Employee Productivity } \\
& =\frac{\text { Operating profit }}{\text { Number of employees }} \times 100 \%
\end{aligned}
$$

Employee productivity indicators aim to measure the increase in employee productivity. Employee productivity is considered good, if during the observation period the results of the calculation of employee productivity have increased, it is considered fair if it is constant and is judged to be poor if it has decreased.

In this study the level of employee satisfaction will be measured by questionnaire.

\section{Data Analysis Technique}

a. Financial Perspective

Financial performance is measured by the following Value for Money measurement scales.

Table 1: Performance Measurement Scale Value for Money

\begin{tabular}{ccc}
\hline PERCENTAGE SCALE & CATEGORY \\
\hline \multicolumn{3}{c}{ ECONOMICAL } \\
\hline$<90 \%$ & 5 & Very Economical \\
$90 \%-95 \%$ & 4 & Economical \\
$95 \%-100 \%$ & 3 & Fairly Economical \\
$100 \%-105 \%$ & 2 & Not Economical \\
$>105 \%$ & 1 & Very \\
\multicolumn{3}{c}{ Uneconomical } \\
\hline \multicolumn{3}{c}{ EFFECTIVENESS } \\
$90 \%-100 \%$ & 5 & Very Effective \\
$80 \%-90 \%$ & 3 & Fairly Effective \\
$60 \%-80 \%$ & 2 & Ineffective \\
$<60 \%$ & 1 & Very Ineffective \\
\hline \multicolumn{3}{c}{ EFFICIENCY } \\
\hline$<60 \%$ & 5 & Very Efficient \\
$60 \%-79 \%$ & 4 & Efficient \\
$80 \%-99 \%$ & 3 & Fairly Efficient \\
$100 \%-120 \%$ & 2 & Not efficient \\
$>120 \%$ & 1 & Very Inefficient \\
\hline
\end{tabular}

Sources: Sugiyono, 2010: 93 and Kepmendagri No. 680,900327 in 1996

b. Customer Perspective

Customer Retention is measured by the following measurement scale: 
Table 2: Customer Perspective

Measurement Scale

\begin{tabular}{ccc}
\hline PERCENTAGE & SCALE & CATEGORY \\
\hline \multicolumn{3}{c}{ CUSTOMER RETENTION } \\
\hline$>80 \%$ & 5 & Very Good \\
$60 \%-80 \%$ & 4 & Good \\
$40 \%-59,9 \%$ & 3 & Fair \\
$20 \%-39,9 \%$ & 2 & Poor \\
$<20 \%$ & 1 & Very Poor \\
\hline \multicolumn{3}{c}{ CUSTOMER ACQUISITION } \\
\hline $80 \%-100 \%$ & 5 & Very Good \\
$60 \%-80 \%$ & 4 & Good \\
$40 \%-60 \%$ & 3 & Fair \\
$20 \%-40 \%$ & 2 & Poor \\
$0 \%-20 \%$ & 1 & Very Poor \\
\hline \multicolumn{4}{c}{ CUSTOMER SATISFACTION } \\
\hline $81.26 \%-100 \%$ & 4 & Very Good \\
$62.51 \%-81.25 \%$ & 3 & Good \\
$43.76 \%-62.5 \%$ & 2 & Poor \\
$25 \%-43.75$ & 1 & Very Poor \\
\hline
\end{tabular}

Source: Sugiyono, 2010

c. Internal Business Perspective

Internal Business Perspective is measured by the following measurement scale:

Table 3: Internal Business Perspective Measurement Scale

\begin{tabular}{|c|c|c|}
\hline PERCENT-AGE & $\overline{\mathrm{SCA}}$ & ATEGORY \\
\hline \multicolumn{3}{|c|}{ Bed Occupancy Rate (BOR) } \\
\hline $60-85 \%$ & 2 & Ideal \\
\hline $\begin{array}{c}60-85 \%<X<60- \\
85 \%\end{array}$ & 1 & Not Ideal \\
\hline \multicolumn{3}{|c|}{ Average Length of Stay (ALOS) } \\
\hline 6-9 days & 2 & Ideal \\
\hline $\begin{array}{c}6-9 \text { days }<\mathrm{X}<6-9 \\
\text { days }\end{array}$ & 1 & Not Ideal \\
\hline \multicolumn{3}{|c|}{ Turn Over Internal (TOI) } \\
\hline $1-3$ days & 2 & Ideal \\
\hline $\begin{array}{c}1-3 \text { days }<X<1-3 \\
\text { days }\end{array}$ & 1 & Not Ideal \\
\hline \multicolumn{3}{|c|}{ Net Death Rate (NDR) } \\
\hline$\leq 25$ & 2 & Ideal \\
\hline$>25$ & 1 & Not Ideal \\
\hline \multicolumn{3}{|c|}{ Gross Death Rate (GDR) } \\
\hline$\leq 45$ & 2 & Ideal \\
\hline$>45$ & 1 & Not Ideal \\
\hline
\end{tabular}

Source: Department of Health RI, 2005

d. Learning and Growth Perspective
The following is a measurement scale on the four indicators of learning performance and growth, namely Employee Retention, Employee Training, Employee Productivity, and Employee Satisfaction.

Table 4: Learning and Growth Perspective Scale

\begin{tabular}{|c|c|c|}
\hline $\begin{array}{c}\text { THE CALCUL- } \\
\text { ATION } \\
\text { RESULTS } \\
\end{array}$ & SCALE & CATEGORY \\
\hline \multicolumn{3}{|c|}{ Employee Retention Scale } \\
\hline Decrease & 3 & Good \\
\hline Constant & 2 & Fair \\
\hline Increase & 1 & Poor \\
\hline \multicolumn{3}{|c|}{ Employee Training Scale } \\
\hline Enhancement & 3 & Good \\
\hline Constant & 2 & Fair \\
\hline Decrease & 1 & Poor \\
\hline \multicolumn{3}{|c|}{ Employee Productivity Scale } \\
\hline Increased & 3 & Good \\
\hline Constant & 2 & Fair \\
\hline Decrease & 1 & Poor \\
\hline \multicolumn{3}{|c|}{ Employee Satisfaction } \\
\hline $81.26 \%-100 \%$ & 4 & Very Good \\
\hline $62.51 \%-81.25 \%$ & 3 & Good \\
\hline $43.76 \%-62.5 \%$ & 2 & Poor \\
\hline $25 \%-43.75$ & 1 & Very Poor \\
\hline
\end{tabular}

Source: Business Feasibility Assessment and Sugiyono, 2010

\section{RESEARCH RESULTS AND DISCUSSION}

The following is the analysis of dr. $\mathrm{H}$. Soewondo Kendal Hospital's performance:

\section{Financial Perspective}

Performance standards set by the government can still be developed further such as the measurement of economic ratios, effectiveness, and efficiency as conducted in this study. To obtain an overview of the financial performance of dr. H. Soewondo Kendal Hospital, researchers used secondary 
data by documenting financial data from the hospital. The financial performance measurement is as follows:

Table 5: Recapitulation of Financial

Perspective Analysis

\begin{tabular}{|c|c|c|c|}
\hline ASPECT & $\begin{array}{l}\text { PERCE- } \\
\text { NTAGE }\end{array}$ & $\begin{array}{c}\text { SCOR } \\
\mathrm{E}\end{array}$ & $\begin{array}{c}\text { CATEGOR } \\
\mathrm{Y} \\
\end{array}$ \\
\hline Economical & $84.16 \%$ & 5 & $\begin{array}{c}\text { Very } \\
\text { Economical } \\
\text { Fairly }\end{array}$ \\
\hline Effectiveness & $85.09 \%$ & 3 & $\begin{array}{l}\text { Effective } \\
\text { Very }\end{array}$ \\
\hline Efficiency & $10.13 \%$ & 5 & Efficient \\
\hline TOTAL & $86.6 \%$ & 1 & Excellent \\
\hline
\end{tabular}

The total percentage generated from the financial performance is $86.6 \%$, so it is included in scale 1 , which is categorized as "Excellent".

\section{Customer Perspective}

Three indicators are used to measure the performance of the customer perspective namely customer retention, customer acquisition and customer satisfaction. The measurement of customer's perspective is described as follows:

Table 6: Recapitulation of Customer Perspective Analysis

\begin{tabular}{lccc}
\hline ASPECT & $\begin{array}{c}\text { PERCE- } \\
\text { NTAGE }\end{array}$ & $\begin{array}{c}\text { SCOR } \\
\text { E }\end{array}$ & $\begin{array}{c}\text { CATE- } \\
\text { GORY }\end{array}$ \\
\hline $\begin{array}{l}\text { Customer } \\
\text { Retention }\end{array}$ & $52.64 \%$ & 3 & Fair \\
$\begin{array}{l}\text { Customer } \\
\text { Acquisition }\end{array}$ & $60.76 \%$ & 4 & Good \\
$\begin{array}{l}\text { Customer } \\
\text { Satisfaction }\end{array}$ & $80.21 \%$ & 3 & Good \\
\hline \multicolumn{1}{c}{ TOTAL } & $71.42 \%$ & 3 & Good \\
\hline
\end{tabular}

The total percentage resulting from the calculation of financial performance is
$71.42 \%$, so it is included in a scale of 3 , which is categorized as "Good".

\section{Internal Business Process Perspective}

The internal business perspective is measured by quality service indicators established by the Ministry of Health of Republic of Indonesia. Five indicators are used to measure the performance of the customer perspective.

Table 7: Recapitulation of Internal Business Perspective Analysis

\begin{tabular}{|c|c|c|c|}
\hline ASPECT & $\begin{array}{l}\text { PERCE- } \\
\text { NTAGE }\end{array}$ & $\begin{array}{c}\text { SCOR } \\
\text { E }\end{array}$ & $\begin{array}{l}\text { CATE- } \\
\text { GORY }\end{array}$ \\
\hline $\begin{array}{l}\text { Bed Occupancy } \\
\text { Rate }\end{array}$ & $85.48 \%$ & 1 & Not Ideal \\
\hline $\begin{array}{l}\text { Average Length } \\
\text { of Stay }\end{array}$ & 4.69 days & 1 & Not Ideal \\
\hline $\begin{array}{l}\text { Turn Over } \\
\text { Internal }\end{array}$ & 0.84 days & 1 & Not Ideal \\
\hline Net Death Rate & 3.1 & 1 & Not Ideal \\
\hline Gross Death Rate & 58.02 & 1 & Not Ideal \\
\hline TOTAL & $50 \%$ & 4 & FAIR \\
\hline
\end{tabular}

Overall, it can be concluded that the internal business perspective of $\mathrm{dr}$. $\mathrm{H}$. Soewondo Kendal Hospital occupies a scale of 4 percentages of $50 \%$ with the category of "Fair".

\section{Learning and Growth Perspective}

Learning and growth aspects are used to identify how far the development of dr. $\mathrm{H}$. Soewondo Kendal Hospital. Measurement of performance learning and growth perspective uses 4 indicators namely employee retention, employee training levels, employee productivity, and employee satisfaction levels. 
Table 8: Recapitulation of Internal Business Perspective Analysis

\begin{tabular}{lccc}
\hline \multicolumn{1}{c}{ ASPECT } & $\begin{array}{c}\text { PERCE- } \\
\text { NTAGE }\end{array}$ & $\begin{array}{c}\text { SC } \\
\text { OR } \\
\text { E }\end{array}$ & $\begin{array}{c}\text { CATE } \\
\text { GORY }\end{array}$ \\
\hline $\begin{array}{l}\text { Employee } \\
\text { Retention }\end{array}$ & $\begin{array}{c}\text { Enhancement } \\
0.28 \%\end{array}$ & 1 & Poor \\
$\begin{array}{l}\text { Employee } \\
\text { Training Level }\end{array}$ & $\begin{array}{c}\text { Enhancement } \\
0.73 \%\end{array}$ & 3 & Good \\
$\begin{array}{l}\text { Employee } \\
\text { Productivity }\end{array}$ & $\begin{array}{c}\text { Decrease IDR } \\
9,137,662\end{array}$ & 1 & Poor \\
$\begin{array}{l}\text { Employee } \\
\text { Satisfaction }\end{array}$ & $79.07 \%$ & 3 & Good \\
Level & $61.54 \%$ & 3 & Good \\
\hline \multicolumn{1}{c}{ TOTAL } & & & \\
\hline
\end{tabular}

Having a total of $61,54 \%$ and a scale of 3 , it can be concluded that the perspective of Learning and Growth of the hospital is declared as "Good".

\section{Overall Performance Analysis of the}

\section{Balance Scorecard Perspective}

Based on the results of four perspectives above, the overall performance of the hospital is as follows:

Table 9: Results of Analysis of Overall

Performance

\begin{tabular}{|c|c|c|c|c|c|}
\hline NO & $\begin{array}{c}\text { PERS- } \\
\text { PECTIVE }\end{array}$ & $\begin{array}{c}\text { SCO } \\
\text { RE }\end{array}$ & $\begin{array}{l}\text { TOTAL } \\
\text { SCORE }\end{array}$ & $\begin{array}{l}\text { WEI } \\
\text { GHT }\end{array}$ & $\%$ \\
\hline 1 & Financal & 13 & 15 & $\begin{array}{c}19.4 \\
\%\end{array}$ & $\begin{array}{c}16.80 \\
\%\end{array}$ \\
\hline 2 & Customer & 10 & 14 & $\begin{array}{c}30.6 \\
\%\end{array}$ & $\begin{array}{c}21.85 \\
\%\end{array}$ \\
\hline 3 & $\begin{array}{l}\text { Internal } \\
\text { Business } \\
\text { Processes }\end{array}$ & 5 & 10 & $\begin{array}{c}19.4 \\
\%\end{array}$ & $9.7 \%$ \\
\hline \multirow[t]{2}{*}{4} & $\begin{array}{l}\text { Learning } \\
\text { and } \\
\text { Growth }\end{array}$ & 8 & 13 & $\begin{array}{c}30.6 \\
\%\end{array}$ & $\begin{array}{c}18.82 \\
\%\end{array}$ \\
\hline & Total & 36 & 52 & $\begin{array}{c}100 \\
\%\end{array}$ & $\begin{array}{c}67.17 \\
\%\end{array}$ \\
\hline
\end{tabular}

From table 9, it can be concluded that the performance of dr. H. Soewondo Kendal Hospital using Balance Scorecard approach is considered as "Good" with a scale of 3 and scored $67.17 \%$.

The financial performance of $\mathrm{dr}$. $\mathrm{H}$. Soewondo Kendal Hospital by using the concept of Value for Money is categorized as "Excellent". The total Operating Expenditures is IDR 144,496,607,926.00 and the realization is IDR $121,612,364,513.00$, so the economic ratio is only $84.16 \%$. Hospital revenue budget is IDR 120,000,000,000, while the realization is less than the target of IDR $102,111,706,253$. The realization that less than the target leads to an effectiveness ratio of $85.09 \%$. Furthermore, the efficiency ratio of dr. H. Soewondo Kendal Hospital is accounted for $10.13 \%$.

The customer perspective performance of dr. H. Soewondo Kendal Hospital is categorized as "Good". Customer retention is in the category of "Fair", Customer acquisition is categorized as "Good" and Customer satisfaction is categorized as "Good".

The perspective of internal business processes obtains a score of 5 out of a total score of 10 and is categorized as "Fair". Indicators of BOR, ALOS, TOI, NDR, GDR are rated as "Not Ideal" because the values 
are not in accordance with the standards set by the Ministry of Health.

The performance of learning and growth perspectives obtains a score of $8(61.54 \%)$ out of 13 with the category "Good". The employee retention is rated as "Poor", employee training is "Good", employee productivity is "Poor" and employee satisfaction is rated as "Good".

Overall performance from four perspectives obtains a total score of 37 out of 52 (sixteen indicators). Therefore, the overall performance of the hospital is in a "Good" category. Performance indicators that are categorized as good or very good needs to be maintained and improved whenever they are possible while some lack of performance needs to be addressed with the appropriate strategies.

\section{CONCLUSIONS AND SUGGESTIONS}

\section{Conclusion}

This study aims to analyze the performance measurement of dr. $\mathrm{H}$. Soewondo Kendal Hospital with Balance Scorecard approach. This research is expected to be a future reference for hospital management planning to improve its performance.

The financial performance of the hospital is considered to be very economical, fairly effective, and very efficient.
The performance of dr. H. Soewondo Kendal Hospital in customer perspective is categorized as "Good". In addition, the level of customer retention reaches $52.64 \%$ (fair), customer acquisition is $60.76 \%$ (good), and customer satisfaction is $80.21 \%$ (good).

The performance of dr. H. Soewondo Kendal Hospital in internal business processes perspective is categorized as "Fair". The measurements of Bad Occupancy Rate (BOR), Average Length of Stay (ALOS), Turn Over Internal (TOI), Net Death Rate (NDR), and Gross Death Rate (GDR) indicators are rated "Not Ideal".

The performance of dr. H. Soewondo Kendal Hospital in learning and growth perspectives is categorized "Good". The employee retention indicator is rated as "Poor" with an increase by $0.28 \%$. The employee training level indicator is rated "Good" with an increase by $0.73 \%$. The employee productivity is rated "Poor" with a score of 1 because it has decreased by IDR $9,137,662$. The last indicator of employee satisfaction is rated "Good" with a score of 3 because it has a percentage of $79.07 \%$.

The performance of dr. H. Soewondo Kendal Hospital in four perspectives obtains a total score 36 out of 52 and reaches a weight of $67.17 \%$. Therefore, the overall performance is categorized as "Good".

\section{Suggestions}

a. Financial Perspective 
The hospital needs to pay more attention to which posts are experiencing deficits, so that unnecessary expenses can be cut. This can increase savings and ultimately obtain a better economic value. The hospital needs to analyze its programs to increase its efficiency.

b. Customer Perspective

In maintaining its relationship with customers (patients), the hospital needs to apply more effective strategies to bind patients. Hospital's ability to attract customers must be improved.

c. Internal Business Process Perspective

All internal business perspective indicators are rated as "Not Ideal". The service quality calls for improvement strategy. In terms of BOR and TOI, they can be managed by increasing the number of beds available for patient care while in terms of ALOS, NDR and GDR, they can be handled by improving the quality of hospital service.

d. Learning and Growth Perspective

Dr. H. Soewondo Kendal Hospital needs to evaluate employee retention by increasing employee welfare (balancing workload and salary, effective recruitment, and giving appreciation). The hospital also needs to conduct routine evaluations, communicating targets clearly, use technology appropriately, and conduct employee self-development programs.

\section{REFERENCE}

Alirafi, I. (2019). Analisis Pengukuran Kinerja dengan Pendekatan Balanced Scorecard pada Sekolah Pondok Pesantren Modern Bina Umat. Faculty of Economics. Yogyakarta State University. Yogyakarta.

Department of Health RI. (2005). Law of The Republic of Indonesia Number 23 of 2005

Kaplan, R. S., \& David, P. N. (2000). Balanced Scorecard, Menerapkan Strategi Menjadi Aksi. Jakarta: Erlangga.

Kaplan, R. S., \& David, P. N. (2001). The Strategy Focused Organization: How Balanced Scorecard Companies Thrive in the New Business Environment. Massachusetts: Harvard Business School Press.

Luis, S., \& Prima, A. B. (2007). Step by Step in Cascading Balanced Scorecard to Functional Scorecards. Jakarta: PT Gramedia Pustaka Utama.

Mardiasmo. (2002). Akuntansi Sektor Publik. Yogyakarta: Andi.

Mulyadi. (2001). Balanced Scorecard: Alat Manajemen Kontemporer Untuk Memperlipatgandakan Kinerja Keuangan Perusahaan. Jakarta: Salemba Empat.

Sugiyono. (2010). Metode Penelitian Pendidikan Pendekatan Kuantitatif, kualitatif, dan $R \& D$. Bandung: Alfabeta.

Sugiyono. (2017). Metode Penelitian Kuantitatif, Kualitatif dan $R \& D$. Bandung: Alfabeta.

Wibowo. (2011). Manajemen Kinerja. Jakarta: Raja Grafindo Persada. 